\title{
Design and Analysis of Financial Condition Local Government Java and Bali (2013-2014)
}

\author{
Nur Dewi Natrini ${ }^{1}$ and Irwan Taufiq Ritonga ${ }^{2}$ \\ ${ }^{1}$ Fellowship of Magister of Accounting, Gadjah Mada University, Yogyakarta, Indonesia \\ ${ }^{2}$ Lecturer of Magister of Accounting, Gadjah Mada University, Yogyakarta, Indonesia
}

\begin{abstract}
This research aims to identify financial condition of local government in Java and Bali year 20132014. It is due to government financial condition, according to several researchers, provides an image on the ability of a government in fulfilling their obligations whether in the form of debt or service fulfillment in timely manner. According to assessment upon financial condition, local government is able to identify how to fulfill public needs, how to utilize resources and how to proceed resources so that it can be more productive. As for the measurement method of financial condition itself, the standard method cannot be determined. Therefore, indicator used for measuring local government financial condition is Brown's (1993)[2] indicator development adjusted to Indonesian government. In order to develop the indicator, this research employs qualitative method by comparing GASB No.34, SAP Government Regulation ("Peraturan Pemerintah" - PP) 71 Year 2010, SAP PP 24 year 2005 and literature studies and expert validation. In order to obtain a balanced comparison, this research also employs clusters developed by Baidori (2015)[1] for government in Java and Bali. Results of this research showed that among 7 analyzed clusters, there are variations of results, even though each cluster has similar socioeconomic condition to each other. This variation upon Indonesian local government financial condition is caused by regional autonomy.

Key words: Financial condition analysis, indicator, cluster, regional autonomy
\end{abstract}

\section{Introduction}

Law Number 23 year 2014 on Local Government defines hat regional autonomy refers to rights, authorities and obligations of a region to govern and manage their government and community interest in their local region. Implementation of regional autonomy leads to a quite enormous flow of funds from central government to local government (Syahruddin, 2006)[21]. In 2006, there was an increase of fund transfer to local government as many as Rp647 quintillion compared to fund transfer in 2014 that was Rp596.5 quintillion (Directorate General of Budget, 2015). Transfer of State Budget ("Anggaran Pendapatan Belanja Negara" - APBN) fund is used to optimize the role of local government in guiding and coordinating governmental implementation, including to manage their finance, whether between province and vertical instances, inter-vertical instances and between regions or cities (PP No. 19 Year 2010)[13].

However, central government only makes available of principles of local financial management without detailed provisions about its management (Ritonga et al., 2012a). As a result, each region has its own programs and activities that different from each other, according to their own local needs and potentials (Prita, 2015). Differences of programs and activities done in each region will lead to difference in allocating budget (Ritonga et al., 2012a , 2012b). Incidence of the difference in budget allocation will lead to a different financial condition among local governments (Ritonga et al., 2012a , 2012b)[15,16]

Financial condition describes the ability of a government in fulfilling their obligations whether in the form of debt or service fulfillment in timely manner (Wang et al., 2007 and Kioko, 2013)[22,7]. According to assessment upon financial condition, local government is able to identify how to fulfill public needs, how to utilize resources and how to proceed resources so that it can be more productive (Williams, 2003)[24]. The importance of financial condition measurement was illustrated by Wang and Liou (2009)[23] as a checking upon human health, financial condition health of an organization which is considered as a complex and a multidimensional matter so that every change in any financial condition will affect other parts.

This research developed a new indicator using Brown (1993)[2] indicator analysis tool which was adjusted to the condition in Indonesia. The result of those indicators was used to measure financial condition of governments in

\footnotetext{
${ }^{1}$ Corresponding author: dewi.natrini@gmail.com
} 
Java and Bali. However, in order to generate a balanced financial condition analysis, this research utilized cluster technique as developed by Baidori (2015)[1]. This goes along with Zafra-Gómez (2009)[25] who stated that if financial condition measurement model is equipped with the implementation of cluster analysis, i.e., by categorizing local government in a similar socioeconomic characteristic, the result of the financial condition evaluation will be much more effective. The new development of financial condition indicators was based on assessment upon financial condition which has no system that can be generally implemented (Wang et al., 2007)[22].

\section{Literature Review}

\subsection{Definition of Local Government Financial Condition}

Generally, financial condition is defined as an ability of a government in fulfilling their obligations whether in the form of debt or service fulfillment in continuous and timely manner (Kioko, 2013 dan Wang et al., 2007)[7 dan 22]. The same issues was expressed by Hruza (2015)[6] that provision of service and materials needed by community is an irreplaceable role of government in modern democracy era. Several researchers have different terms of financial condition, among others are

Table 1. Terms of Financial Condition

\begin{tabular}{|c|l|}
\hline Researchers & \multicolumn{1}{|c|}{ Terms } \\
\hline Crosby and Robbin (2013)[27] & $\begin{array}{l}\text { Fiscal Health, refers to a primary determiner of government ability } \\
\text { in fulfilling desire and needs of their community. }\end{array}$ \\
\hline $\begin{array}{c}\text { Cabaleiro et al. (2012) and } \\
\text { Cuadro-Ballestros et al. (2013) } \\
{[28,29]}\end{array}$ & $\begin{array}{l}\text { Financial Health, is described as the main requirement in fulfilling } \\
\text { the aim of any institutions. }\end{array}$ \\
\hline $\begin{array}{c}\text { Kloha et al. (2005) and Trussel } \\
\text { and Patrick (2009)[30,31] }\end{array}$ & $\begin{array}{l}\text { Fiscal Distress, is described as a condition threatening local } \\
\text { government to serve their citizen and to maintain public functions } \\
\text { that are considered as essential functions }\end{array}$ \\
\hline $\begin{array}{c}\text { Brusca et al. (2015)[26] } \\
\text { Financial Sustainability, is defined as an ability in managing the } \\
\text { expected revenue and predicting long term financial risks without } \\
\text { affecting the decrease of revenue or redundancy of expense. }\end{array}$ \\
\hline
\end{tabular}

The most acceptable definition of local government financial condition is referring to the ability of a government in fulfilling their obligations in finance in a timely manner and the ability to maintain services provided for community (Ritonga, 2014)[17].

\subsection{Brown's 10-point test Financial Measurement Model}

Brown (1993)[2] conducted a quick financial condition measurement using 10-point test for financial ratio of local government of which the population is less that 100,000 people. The tools of the corresponding test are established specifically for providing a more focused measurement tool regarding financial condition upon a smaller local government (Rivenbark and Roenigk, 2011)[18]. Ten ratios utilized by Brown (1993)[2] consist of 4 financial fundamental factors including revenue (ratio 1-3), expenditures (ratio 4), operation position (ratio 5-7), and debt structure (ratio 8-10) (Ritonga, 2014; Maher and Nollenberger, 2009)[17,8]. The aim of establishment of 10-point test measurement tools by Brown (1993)[2] is due to the needs of measurement tools of local government financial condition that shall be quick and effective, and also to improve comparative data availability of the city provided from financial indicators.

The strength of Brown's (1993)[2] 10-point test model is on its benchmarking. That comparison is seen from the ranking conducted by Brown from local government starting from the worst to the best aspects according to each category (Rivenbark and Roenigk, 2011; Rivenbark et al., 2010)[18,19]. Brown's financial condition Measurement comprises of 3 steps, among others are: a. Calculating 10 financial ratios based on data in annual financial statements, b. Comparing the ratios between each local government with another according to the same population magnitude. Brown (1993)[2] classified the city by forming the following four categories: (1) a city of which total population is between 50,000-100,000 people, (2) a city of which total population is between 30,000-50,000 people, (3) a city of which total population is between $15,000-30,000$ people, and (4) a city of which total population is less than 15.000 people, c. Conducting a ranking upon local financial condition according to the classification specified on the second step, starting from the best local government to the worst local government. 


\subsection{Clustering Results by Baidori (2015) in Indonesian context}

Local government financial condition analysis will be more meaningful and useful if the local governments involved are classified into some categories with the same characteristics (Priyambodo and Ritonga, 2014)[32]. Data in the process of cluster forming developed by Baidori (2015)[1] includes eight variables of General Allocation Fund calculation components, i.e. total population; local area; Human Development Index; Construction Cost Index; Gross Regional Domestic Product ("Produk Domestik Regional Bruto" - PDRB) per capita; Own-Source Revenue ("Pendapatan Asli Daerah" - PAD); Tax Revenue Sharing Fund (Dana Bagi Hasil Penerimaan Pajak) and Natural Resources Revenue Sharing Fund (Dana Bagi Hasil Penerimaan Sumber Daya Alam). According to clustering results from Baidori (2015)[1], there are 5 clusters in city group and 6 clusters in regional group formed. The following are translation of each cluster of both city and regional groups.

Table 2 City Cluster

\begin{tabular}{|c|c|c|c|}
\hline \multirow[t]{7}{*}{ Cluster 1} & Batu & \multirow[t]{12}{*}{ Cluster 2} & Blitar \\
\hline & Mojokerto & & Cilegon \\
\hline & Pasuruan & & Denpasar \\
\hline & Probolinggo & & Madiun \\
\hline & Semarang & & Magelang \\
\hline & Serang & & Pekalongan \\
\hline & Tasikmalaya & & Salatiga \\
\hline \multirow[t]{9}{*}{ Cluster 4} & Bandung & & Surakarta \\
\hline & Banjar & & Tangerang \\
\hline & Bekasi & & Tangerang Selatan \\
\hline & Bogor & & Tegal \\
\hline & Cimahi & & Yogyakarta \\
\hline & Cirebon & Cluster 3 & Surabaya \\
\hline & Depok & Cluster 5 & Kediri \\
\hline & Malang & & \\
\hline & Sukabumi & & \\
\hline
\end{tabular}

Table 3 Region Cluster

\begin{tabular}{|c|c|c|c|c|c|}
\hline \multirow[t]{24}{*}{ Cluster 1} & Bandung Barat & Kendal & Purbalingga & \multirow[t]{8}{*}{ Cluster 2} & Bandung \\
\hline & Bangli & Klaten & Purwakarta & & Banyuwangi \\
\hline & Banjarnegara & Klungkung & Purworejo & & Cianjur \\
\hline & Bantul & Kudus & Rembang & & Garut \\
\hline & Banyumas & Kulon Progo & Semarang & & Jember \\
\hline & Batang & Kuningan & Serang & & Malang \\
\hline & Blitar & Lamongan & Situbondo & & Sukabumi \\
\hline & Blora & Lebak & Sleman & & Tasikmalaya \\
\hline & Bondowoso & Lumajang & Sragen & Cluster 3 & Badung \\
\hline & Boyolali & Madiun & Subang & \multirow[t]{4}{*}{ Cluster 4} & Bangkalan \\
\hline & Brebes & Magelang & Sukoharjo & & Pamekasan \\
\hline & Buleleng & Magetan & Sumedang & & Sampang \\
\hline & Ciamis & Majalengka & Tabanan & & Sumenep \\
\hline & Cirebon & Mojokerto & Tegal & \multirow[t]{8}{*}{ Cluster 5} & Bekasi \\
\hline & Demak & Nganjuk & Temanggung & & Bogor \\
\hline & Grobogan & Ngawi & Trenggalek & & Cilacap \\
\hline & Gunung Kidul & Pacitan & Tuban & & Gresik \\
\hline & Jembrana & Pandeglang & Tulungagung & & Indramayu \\
\hline & Jepara & Pati & Wonogiri & & Karawang \\
\hline & Jombang & Pasuruan & Wonosobo & & Sidoarjo \\
\hline & Karanganyar & Pekalongan & & & Tangerang \\
\hline & Karangasem & Pemalangan & & Cluster 6 & Bojonegoro \\
\hline & Kebumen & Ponorogo & & & \\
\hline & Kediri & Probolinggo & & & \\
\hline
\end{tabular}




\section{Research Method}

This research employed qualitative method since the researcher aims to explore deeper the financial condition of local government by developing regional financial condition indicators in the first place. Hence, this research utilized development approach model. It was described by Sugiyono (2015)[20] that research and development method is a research method that is used for examining in order to develop an existing product (innovation) or to create a new tested product. Data collection in this research used documentation method. According to Cresswell (2014)[3] during a research process, researcher may gather qualitative documents in the form of public documents (such as newspaper, papers, agency reports) or private documents (such as journal, diary, letters, e-mails). Data of this research were taken from secondary data, i.e., Examination Report ("Laporan Hasil Pemeriksaan" - LHP) of BPK RI upon Student Worksheets ("Lembar Kerja Peserta Didik" - LKPD) in Java and Bali on 2012-2014 LKPD, publication data from Central Bureau of Statistics "Badan Pusat Statistik" - BPS), Regional Medium-term Development Plan ("Rencana Pembangunan Jangka Menengah Daerah" - RPJMD), Annual Local Government Working Plan ("Rencana Kerja Pemerintah Daerah" - RKPD) in 121 local governments.

Translation of this research steps are as follow:

1. Analysis of financial condition measurement method used by Brown (1993)[2] by looking for account equations existing on financial statement in Indonesia on the basis of literature review. According to the corresponding step, a new financial condition measurement is obtained and it will be validated by the experts.

2. Calculating ratio according to annual financial statement and other supporting data

3. Comparing data of inter-local government according to Baidori's (2015) clusters. By comparing the ratio, each local government in each cluster will be classified into 4 quartiles as follow:

a. Quartile $1(0-25 \%)$ shows that local government in particular cluster has a bad ratio according to their rank.

b. Quartile $2(25 \%-50 \%)$ shows that local government in particular cluster has a good ratio according to their rank.

c. Quartile $3(50 \%-70 \%)$ shows that local government in particular cluster has a better ratio according to their rank.

d. Quartile $4(70 \%-100 \%)$ shows that local government in particular cluster has the best ratio according to their rank.

4. Conducting grading or ranking upon regional financial condition according to the scale proposed by Brown (1993)[2]. That scale was designed to enable local government of which the ratio is above 50\% (quartile 3 and above) to obtain a positive total score. It means that local government of which its ratio majority is above $50 \%$ has a better financial condition compared to the local government of which its ratio majority is below $50 \%$ (Brown, 1993). The local government of which ratio is between 50\%-70\% (quartile 3) will receive a total score of 9 points out of 9 financial condition indicators. Meanwhile, the local government of which ratio is between $25 \%-50 \%$ (quartile 2) will receive a total score of zero (0) point, and he local government of which ratio is between $0=25 \%$ (quartile 1 ) will receive a negative total score $(-9)$ points out of the new financial condition indicators.

5. The determination of financial condition upon local government financial condition existing in each cluster. Brown (1993)[2] concluded that local government financial condition is defined according to assessment scale detailed as follow:

Table 4 Assessment Scale of Financial Condition

\begin{tabular}{|l|l|}
\hline \multicolumn{1}{|c|}{ Total score } & \multicolumn{1}{|c|}{$\begin{array}{c}\text { Relative assessment scale upon entire local } \\
\text { governments }\end{array}$} \\
\hline 10 or more & Between the best \\
\hline 5 up to 9 & Better than the most cities \\
\hline 1 up to 4 & Average \\
\hline 0 up to -4 & Worse than the most cities \\
\hline-5 or less & Between the worst \\
\hline
\end{tabular}

\section{Research Findings and Discussion}

\subsection{Indicators of Financial Condition according to the version of Indonesian Government}


Analysis of local government financial condition in Java and Bali area is measured using modified indicators that were referring to measurement tools developed by Brown (1993)[2]. The modification of financial condition indicator aims to adjust the measurement tool so that it may run in accordance with financial condition in Indonesia. If Brown (1993)[2], in developing these indicators, used American financial statement under GASB no 34, this research used SPAP of PP 71 year 010 and PP 24 year 2005 and the related laws and regulations.

The following is translation of 10 financial condition indicators developed to measure local government financial condition in Java and Bali areas:

Table 5 New Indicator Translation

\begin{tabular}{|c|c|c|c|}
\hline $\begin{array}{l}\text { Brown Ratio } \\
\text { (1993) }\end{array}$ & Financial Statement of America & Financial Statement of Indonesia & New Ratio Indonesian version \\
\hline $\begin{array}{l}\text { Ratio 1: Total } \\
\text { Revenues / } \\
\text { Population }\end{array}$ & $\begin{array}{l}\text { Total Revenue is a total of all } \\
\text { revenues stated in Governmental } \\
\text { funds statement. The revenues in } \\
\text { the corresponding } \\
\text { statement/report are divided into } \\
4 \text { groups, i.e., General Fund, } \\
\text { Capital Projects Fund, General } \\
\text { Debt Service Fund, Non-major } \\
\text { Governmental Fund }\end{array}$ & $\begin{array}{l}\text { PP } 24 \text { Year } 2005 \text { and PP } 71 \text { Year } \\
2010 \text { divide revenues into type or } \\
\text { source of revenue, they are Own- } \\
\text { Source Revenue ("Pendapatan Asli } \\
\text { Daerah" - PAD), Transfered } \\
\text { Revenue (sharing fund (dana bagi } \\
\text { hasil), general allocation fund (dana } \\
\text { alokasi umum), special allocation } \\
\text { fund (dana alokasi khusus), and } \\
\text { Other Authorized Revenue (Lain-lain } \\
\text { Pendapatan yang Sah). }\end{array}$ & $\begin{array}{l}\text { Ratio 1: (Total Revenue - } \\
\text { Special Allocation Fund (Dana } \\
\text { Alokasi Khusus) - DAK)) } \\
\text { Population } \\
\text { Interpretation: High ratio, } \\
\text { showing a bigger ability to } \\
\text { obtain supplementary revenue }\end{array}$ \\
\hline \multirow{2}{*}{$\begin{array}{l}\text { Ratio 2: Total } \\
\text { General Funds } \\
\text { Revenue from } \\
\text { own sources / } \\
\text { Total General } \\
\text { Revenue }\end{array}$} & \multirow{2}{*}{$\begin{array}{l}\text { General fund form own resources } \\
\text { account according to American } \\
\text { Government statement/report is: } \\
\text { Taxes (Real estate, Sales and use, } \\
\text { Personal income, Other) } \\
\text { General revenue account } \\
\text { according to American } \\
\text { Government statement/report } \\
\text { consists of: Taxes (Real estate, } \\
\text { Sales and use, Personal income, } \\
\text { Other), Federal, State, and } \\
\text { another categorical aid, Charges } \\
\text { for services, Investment income, } \\
\text { Other Revenues }\end{array}$} & \multirow{2}{*}{$\begin{array}{l}\text { Law No } 33 \text { Year } 2004 \text { defines that } \\
\text { PAD a revenue obtained by } \\
\text { local/region collected under local } \\
\text { regulations and laws and regulations. } \\
\text { General revenue in American version } \\
\text { is translated in Indonesian } \\
\text { Government financial statement into } \\
\text { PAD, Sharing Fund, provincial tax } \\
\text { sharing and other revenues and DAU. }\end{array}$} & $\begin{array}{l}\text { Ratio } \mathbf{2}: \text { PAD } \\
\text { (PAD+DBH+DAU+Provincial } \\
\text { Tax Sharing Revenue) }\end{array}$ \\
\hline & & & $\begin{array}{l}\text { Interpretation: High ratio, } \\
\text { showing that government does } \\
\text { not rely on external } \\
\text { governmental organization }\end{array}$ \\
\hline $\begin{array}{l}\text { Ratio 3: } \\
\text { General Fund } \\
\text { sources from } \\
\text { other funds / } \\
\text { Total general } \\
\text { fund sources }\end{array}$ & $\begin{array}{l}\text { General Fund Sources Account } \\
\text { from other funds consists of: } \\
\text { Principal Amount bond issued, } \\
\text { Transfer from General debt } \\
\text { service fund, and Transfer From } \\
\text { Non-major Debt Services Fund }\end{array}$ & $\begin{array}{l}\text { Regional revenue out of own-source } \\
\text { revenue according to PP } 24 \text { year } 2005 \\
\text { consists of Regional Fiscal Balance } \\
\text { Funding (Dana Perimbangan) (DBH, } \\
\text { DAU, DAK) and Other Authorized } \\
\text { Revenue. }\end{array}$ & $\begin{array}{l}\text { Ratio 3 : } \\
\text { (DBH+DAU+Provincial Tax } \\
\text { Sharing Revenue+Other } \\
\text { Authorized Revenue)/ } \\
\text { (PAD+DBH+DAU+Provincial } \\
\text { Tax Sharing Revenue) } \\
\text { Interpretation: Low ratio, } \\
\text { showing that government is not } \\
\text { in operational transfer to fund } \\
\text { general government operational }\end{array}$ \\
\hline $\begin{array}{l}\text { Ratio 4: } \\
\text { Operating } \\
\text { expenditures / } \\
\text { Total } \\
\text { Expenditures }\end{array}$ & $\begin{array}{l}\text { Operating expenditures account } \\
\text { consists of: General Government, } \\
\text { Public safety and Judicial, } \\
\text { Education, City University, } \\
\text { Social Services, Environmental } \\
\text { protection, Transportation } \\
\text { Services, Parks, recreation, and } \\
\text { cultural activities } \\
\text { Total expenditures account } \\
\text { consists of: General Fund, Capital } \\
\text { Projects Fund, General Debt } \\
\text { Services Fund. }\end{array}$ & $\begin{array}{l}\text { PP } 71 \text { year } 2010 \text { describes } \\
\text { operational expenditure as budget } \\
\text { expense for daily activities of local } \\
\text { government that are beneficial for } \\
\text { short terms. } \\
\text { Expenditure, according to PP } 71 \text { Year } \\
2010 \text {, is classified into three } \\
\text { classifications, they are: Operational } \\
\text { expenditure, Capital Expenditure and } \\
\text { Unforeseen Expenditure. }\end{array}$ & $\begin{array}{l}\text { Ratio 4: Operational } \\
\text { expenditure / Total Expenditure } \\
\text { Interpretation: Low ratio, } \\
\text { showing that the infrastructure } \\
\text { is well-maintained }\end{array}$ \\
\hline
\end{tabular}




\begin{tabular}{|c|c|c|c|}
\hline $\begin{array}{c}\text { Brown Ratio } \\
\text { (1993) }\end{array}$ & Financial Statement of America & Financial Statement of Indonesia & New Ratio Indonesian version \\
\hline $\begin{array}{l}\text { Ratio 5: Total } \\
\text { Revenues / } \\
\text { Total } \\
\text { Expenditures }\end{array}$ & $\begin{array}{l}\text { Total Revenues and Total } \\
\text { Expenditures account consist of: } \\
\text { General Fund, Capital Projects } \\
\text { Fund, General Debt Services } \\
\text { Fund. }\end{array}$ & $\begin{array}{l}\text { Revenue account in Indonesian } \\
\text { Government financial statement } \\
\text { consists of: PAD, Transfered } \\
\text { Revenue and other authorized } \\
\text { revenue. }\end{array}$ & $\begin{array}{l}\text { Ratio 5: (Total Revenue - } \\
\text { DAK) / (Total Expenditure- } \\
\text { DAK) } \\
\text { Interpretation: High ratio, } \\
\text { showing that local government } \\
\text { experiences positive equity } \\
\text { between periods }\end{array}$ \\
\hline $\begin{array}{l}\text { Ratio 6: } \\
\text { Unreserved } \\
\text { general fund } \\
\text { balance / Total } \\
\text { general } \\
\text { General } \\
\text { Revenue }\end{array}$ & $\begin{array}{l}\text { Formula for unreserved general } \\
\text { fund balance in American } \\
\text { Version is_Revenue - } \\
\text { Expenditure - Other Financing } \\
\text { Uses - Other Financing Sources } \\
\text { + Fund Balance at the Beginning } \\
\text { Year (Only for accounts in } \\
\text { general fund) }\end{array}$ & $\begin{array}{l}\text { Unreserved Fund Balance account in } \\
\text { Indonesian version is: PAD + DBH+ } \\
\text { DAU+ Provincial Tax Sharing and } \\
\text { other revenues - Operating Costs + } \\
\text { Unreserved Fund Balance in } \\
\text { Indonesian version of the previous } \\
\text { year. }\end{array}$ & $\begin{array}{l}\text { PAD + DBH+ DAU+ Provincial } \\
\text { Tax Sharing and other revenue - } \\
\text { Operating Costs + Unreserved } \\
\text { Fund Balance in Indonesian } \\
\text { version of the previous year / } \\
\text { (PAD + DBH + DAU + Sharing } \\
\text { Revenue } \\
\text { + Other authorized revenue). } \\
\text { Interpretation: High ratio, } \\
\text { showing that there is a resource } \\
\text { that can be utilized to overcome } \\
\text { temporary shortcomings of short } \\
\text { term liabilities }\end{array}$ \\
\hline $\begin{array}{l}\text { Ratio 7: Total } \\
\text { general fund } \\
\text { cash and } \\
\text { investments / } \\
\text { Total General } \\
\text { Fund Liabilities }\end{array}$ & $\begin{array}{l}\text { General Fund Account- Balance } \\
\text { Sheet: Cash and Cash equivalent, } \\
\text { and Investment. Total General } \\
\text { Fund Liabilities: Accounts } \\
\text { payable and accrued liabilities, } \\
\text { Accrued tax refunds, Accrued } \\
\text { judgments and claims, Due to } \\
\text { component units, Estimated dis- } \\
\text { allowanced of federal state and } \\
\text { other aid, and Other liabilities. }\end{array}$ & $\begin{array}{l}\text { Account in financial statement } \\
\text { balance sheet in Indonesia: Cash and } \\
\text { cash equivalent, short-term } \\
\text { investment, Third Party Calculation } \\
\text { debt, domestics total assets part, other } \\
\text { short-term debt, other long-term total } \\
\text { assets. }\end{array}$ & $\begin{array}{l}\text { Ratio 7: (Cash + Short-term } \\
\text { Investment) / Short-term } \\
\text { liabilities. } \\
\text { Interpretation: High ratio, } \\
\text { showing sufficiency of cash and } \\
\text { cash equivalent that can be used } \\
\text { to pay off short-term liabilities }\end{array}$ \\
\hline $\begin{array}{l}\text { Ratio 8: } \\
\text { General Fund } \\
\text { Liabilities / } \\
\text { Total General } \\
\text { Fund } \\
\text { Revenues }\end{array}$ & $\begin{array}{l}\text { Total General fund liabilities } \\
\text { account is: Accounts payable and } \\
\text { accrued liabilities, Accrued tax } \\
\text { refunds, Accrued judgments and } \\
\text { claims, Due to component units, } \\
\text { Estimated dis-allowanced of } \\
\text { federal state and other aid } \\
\text { General fund revenue account: } \\
\text { Taxes (Real estate, Sales and use, } \\
\text { Personal income, Other), Federal, } \\
\text { State, and another categorical aid, } \\
\text { Charges for services, Investment } \\
\text { income, Other Revenue }\end{array}$ & $\begin{array}{l}\text { Current liabilities account: Third } \\
\text { Party Calculation Debt, Debt Interest, } \\
\text { domestics total assets part, other } \\
\text { short-term debts, other long-term } \\
\text { total assets } \\
\text { General revenue account: } \\
\text { PAD+DBH+DAU+Provincial Tax } \\
\text { Sharing and other Revenues }\end{array}$ & $\begin{array}{l}\text { Ratio 8: Short-term Liabilities/ } \\
\text { (PAD+DBH+DAU+Provincial } \\
\text { Tax Sharing Revenue) } \\
\text { Interpretation: Low ratio, } \\
\text { showing that short-term } \\
\text { liabilities can be only served by } \\
\text { normal flow of annual revenue }\end{array}$ \\
\hline $\begin{array}{l}\text { Ratio 9: Debt } \\
\text { Services } \\
\text { Total } \\
\text { Revenues }\end{array}$ & $\begin{array}{l}\text { General debt services funds } \\
\text { account is Administrative and } \\
\text { other and Debt services (Interest } \\
\text { and Redemptions). } \\
\text { Total revenue account consists of } \\
\text { General Fund, Capital Projects } \\
\text { Fund, General Debt Services } \\
\text { Fund. }\end{array}$ & $\begin{array}{l}\text { According to SAP, interest } \\
\text { expenditure in financial statement of } \\
\text { Indonesian Government is a part of } \\
\text { operational expenditures. } \\
\text { Total revenue account consists of } \\
\text { Own-Source Revenue ("Pendapatan } \\
\text { Asli Daerah" - PAD), Transfered } \\
\text { Revenue (sharing fund (dana bagi } \\
\text { hasil), general allocation fund (dana } \\
\text { alokasi umum), special allocation } \\
\text { fund (dana alokasi khusus), and } \\
\text { Other Authorized Revenue (Lain-lain } \\
\text { Pendapatan yang Sah) }\end{array}$ & $\begin{array}{l}\text { Ratio 9: Interest Expenditure / } \\
\text { (Total Revenue - DAK) } \\
\text { Interpretation: Low ratio, } \\
\text { showing that government is able } \\
\text { to pay off debt requirements on } \\
\text { due date }\end{array}$ \\
\hline
\end{tabular}




\begin{tabular}{|c|c|c|c|}
\hline $\begin{array}{c}\text { Brown Ratio } \\
\text { (1993) }\end{array}$ & Financial Statement of America & Financial Statement of Indonesia & New Ratio Indonesian version \\
\hline $\begin{array}{l}\text { Ratio 10: } \\
\text { Direct Long } \\
\text { Term Debt / } \\
\text { Population }\end{array}$ & $\begin{array}{l}\text { Non-current Liabilities account } \\
\text { consist of Bonds and Note } \\
\text { Payable Due within one year and } \\
\text { Bonds and Note Payable. } \\
\text { Long-term Debt account in ratio } \\
10 \text { is presented in net position } \\
\text { balance sheet in American } \\
\text { financial statement }\end{array}$ & $\begin{array}{l}\text { Account in Indonesian Government } \\
\text { financial statement is long-term } \\
\text { liabilities (foreign debt, banking } \\
\text { sector-domestic debt, obligation } \\
\text { domestic debt, Obligation Premium } \\
\text { (discount), other long-term debt) }\end{array}$ & $\begin{array}{l}\text { Ratio 10: Long-term Debt / } \\
\text { Population } \\
\text { Interpretation: Low ratio, } \\
\text { sowing that government } \\
\text { possesses an ability to pay off } \\
\text { long-term debt }\end{array}$ \\
\hline
\end{tabular}

\subsection{Calculation of each ratio and scoring for Local Government Financial Condition.}

Scoring is the third step after calculation of each ratio in all local governments in each cluster. Scoring value is obtained from the result of financial indicators classification in the four quartiles specified according to Brown's (1993)[2] steps.

Table 6 Example of Score calculation of Pamekasan Region (Kabupaten Pamekasan) year 2014

\begin{tabular}{|c|c|c|c|c|c|c|}
\hline \multirow[t]{3}{*}{ No } & \multirow[t]{3}{*}{ Ratio } & \multicolumn{4}{|c|}{ Points for each quartile } & \multirow[t]{3}{*}{ Score } \\
\hline & & Q1 (0-25\%) & $\begin{array}{c}\text { Q2 (25\%- } \\
50 \%)\end{array}$ & $\begin{array}{c}\text { Q3 (50\%- } \\
75 \%) \\
\end{array}$ & Q4 (75\%-100\%) & \\
\hline & & -1 & $\mathbf{0}$ & 1 & 2 & \\
\hline 1 & Ratio 1 & & & & 2 & 2 \\
\hline 2 & Ratio 2 & & & & 2 & 2 \\
\hline 3 & Ratio 3 & & & & 2 & 2 \\
\hline 4 & Ratio 4 & -1 & & & & -1 \\
\hline 5 & Ratio 5 & & & & 2 & 2 \\
\hline 6 & Ratio 6 & & 0 & & & 0 \\
\hline 7 & Ratio 7 & & 0 & & & 0 \\
\hline 8 & Ratio 8 & -1 & & & & -1 \\
\hline 9 & Ratio 9 & & & & 2 & 2 \\
\hline 10 & Ratio 10 & & & & 2 & 2 \\
\hline \multicolumn{6}{|c|}{ Total Score } & 10 \\
\hline
\end{tabular}

According to table 6, Pamekasan Region has total score of 10. The total score is interpreted according to the rank of financial condition developed by Brown (1993). Pamekasan Region obtains a total score of 10, so that it can be assumed that the financial condition of Pamekasan Region in 2014 is considered as the best condition. Score determination to describe financial condition applies for city/municipal and regional government in each cluster.

\subsection{Analysis of City Government Financial Condition Year 2013-2014}

The next step is to analyze financial government of local government in each cluster. The following is one of the analysis on regional government year 2013-2014 in cluster 2.

Table 7 Score for Financial Condition of Regional Government Year 2013 and 2014(Cluster 2)

\begin{tabular}{|c|c|c|c|}
\hline \multirow{2}{*}{ No } & \multirow{2}{*}{ Regional Government } & \multicolumn{2}{|c|}{ Score } \\
\hline & & 2013 & 2014 \\
\hline 1 & Bandung & 11 & 8 \\
\hline 2 & Banyuwangi & 11 & 12 \\
\hline 3 & Cianjur & 6 & 6 \\
\hline 4 & Garut & 1 & 1 \\
\hline 5 & Jember & 8 & 11 \\
\hline 6 & Malang & 6 & 8 \\
\hline 7 & Sukabumi & 5 & 0 \\
\hline 8 & Tasikmalaya & 8 & 10 \\
\hline
\end{tabular}

Description: 


\begin{tabular}{|l|l|}
\hline The Best \\
\hline Better \\
\hline Average \\
\cline { 2 - 2 } Worse \\
\hline The Worst \\
\hline
\end{tabular}

According to Table 7, it can be identified that the region of which the financial condition is consistent is Banyuwangi Region, with the best financial condition, and Cianjur Region, with a better financial condition. Sukabumi Region experiences a decrease of two ranks in those classifications, from the previous financial condition that shows a better result into a worse financial condition. It is due to the decrease on ratio 1, ratio 2, ratio 3 , and ratio 5 of which almost all of them show score of -1 except for ratio 1 of which the score shown is 0 . Not only significantly decreasing, Sukabumi Region also secures the lowest financial condition in cluster 2. The decrease in ratio 2 and 3 can be defined as that there is a dependence on source from external organization in funding operational of local government compared to the regions in cluster 2 .

\section{Conclusion}

According to the 7 analyzed clusters, there are variations of results, even though each cluster has similar socioeconomic condition to each other. Variation of local government financial condition in Indonesia is caused by regional autonomy as specified in Law Number 23 Year 2014 that defines that regional autonomy refers to rights, authorities and obligations of a region to govern and manage their government and community interest in their local region. It goes along with the research conducted by Ritonga et al. (2012a and 2012b)[15,16] that the differences of programs and activities done in each region will lead to difference in allocating budget. Incidence of the difference in budget allocation will lead to a different financial condition among local governments (Ritonga et al., 2012a and $2012 b)[15,16]$. Shortcomings and limitations of this research, and also as suggestions for the research in the future, are described as follow:

a. This research was only conducted for two years in analyzing the financial condition of local government in Java and Bali. Researches in the future should be able to utilize financial information for more that two years to complete the analysis of financial condition of local government.

b. This research is only limited to Local Governments in Java and Bali that only represent $20 \%$ of all local governments in Indonesia. All of the shortcomings may be used as consideration for the next researches in the future in order to expand research object to enrich the analysis of financial condition of local government in Indonesia.

\section{References}

1. Baidori 2015, 'Pengklasteran Pemerintah Daerah di Jawa dan Bali Berdasarkan Variabel Sosio ekonomi (Komparasi Laporan keuangan Daerah)', Thesis. Yogyakarta: Universitas Gadjah Mada.

2. Brown, KW 1993, The 10-Point Test of Financial Condition: Toward an Esay-to-Use Assessment Tool for Smaller Cities. Government Finance Review, vol. 9, no. 6, pp. 21-26.

3. Creswell, JW 2014, Research Design: Qualitative, Quantitative, and Mixed Methods Approaches, 4th Edition, Sage Publications, California.

4. DJPK 2013, Analisis Realisasi APBD Tahun Anggaran 2012. Direktorat Jenderal Perimbangan KeuanganKementerian Keuangan.

5. Direktorat Jenderal Angggaran (DJPK) 2015, Budget In Brief APBN 2015. Direkotrat Penyusunan Anggaran Republik Indonesia

6. Hruza, F 2015, Public Sector Organization Financial Ratios Recent Development as a Metter of Financial Innovation. Investment Management and Financial Innovations, vol.12, no.2, pp. 88-93.

7. Kioko, SN 2013, Reporting on the Financial Condition of the States 2002-2010. Jurnal of Public Budgeting, Accounting, and Financial Management, vo.25, no.1, pp165-198.

8. Maher, CS, dan Nollenberger, K 2009. Revisiting Kenneth Brown's "10-Point Test." Government Finance Review, vol. 25, no. 5, pp. 61-66.

9. Maher, CS 2013, Measuring Financial Condition: An Essential Element of Management During Periods of Fiscal Stress, The Journal of Government Financial Management, pp. 20.

10. Prita, AD 2015. 'Analisis Kondisi Keuangan Berdasarkan Model Brown'. Skripsi. Yogyakarta: Universitas Gadjah Mada.

11. Republik Indonesia 2005, Peraturan Pemerintah Nomor 24 Tahun 2005 tentang Standar Akuntansi Pemerintahan.

12. Republik Indonesia 2010, Peraturan Pemerintah Nomor 71 Tahun 2010 tentang Standar Akuntansi Pemerintahan. 
13. Republik Indonesia 2010, Peraturan Pemerintah Nomor 19 Tahun 2010 tentang Tata Cara Pelaksanaan Tugas dan Wewenang serta Kedudukan Keuangan Gubernur Sebagai Wakil Pemerintah di Wilayah Provinsi

14. Republik Indonesia 2014, Undang-Undang Nomor 23 Tahun 2014 tentang Pemerintahan Daerah.

15. Ritonga, I, Clark, C, dan Wickremasinghe, G 2012a. Assessing Financial Condition of Local Government in Indonsia: An Exploration. Municipal and Public Finance, vol. 1, no. 2, pp. 37-50.

16. 2012b, "Factors Affecting Financial Condition of Local Government in Indonesia": IIlu. / /www.apira2013.org/proceedings/pdfs/K159.pdf.

17. Ritonga, I 2014, Analisis Laporan Keuangan Pemerintah Daerah, Lembaga Kajian manajemen Pemerintah Daerah, Yogyakarta.

18. Rivenbark, WC, Roenigk, DJ, Allison, GS 2010, Conceptualizing Financial Condition in Local Government, Jurnal of Public Budgeting, Accounting, and Financial Management, vol.22, no. 2, pp. 149-177

19. Rivenbark, WC, dan Roenigk, DJ 2011, Implementation of Financial Condition Analysis in Local Government, Public Administration Quarterly, vol.35, no.2, pp. 241-267

20. Sugiyono 2015, Metode Penelitian dan Pengembangan (Research and Development), Alfabeta: Bandung.

21. Syahrudin 2006, Desentralisasi Fiskal: Perlu Penyempurnaan Kebijakan dan Implementasi

22. Wang, X, Dennis, L, dan Tu, YSJ 2007, Measuring financial condition: A Study of US states, Public Budgeting \& Finance, vol. 27, no. 2, pp. 1-21.

23. Wang, $X$ dan Liou, KT 2009, Assesing the Change in Financial Condition: An Anlaysis of Panel Data From U.S.States, Public Budgeting and Finance, vol.21, no.2, pp.165-197

24. Williams,DW 2003, Measuring Government in the Early Twentieth Century. Public Administration Review, vol.63, no.6, pp.643-659.

25. Zafra-Gomez, JL, Lopez-Hernandez, AM, Hernandez-Bastida, A 2009, Evaluating Service Quality and Minimizing the Effects of the Socioeconomic Environment: An Aplication to Spanish Municipalities. The American Review of Public Administration, vol.39, no.4, pp.425-449.

26. Brusca, I, Rossi, FM, Aversano, N 2015, Drivers for the Financial Condition of Local Government: A Comparative Study Between Italy and Spain. Lex Localis- Journal of Local Self Government, vol.13, no.2, pp.161184

27. Crosby, A, dan Robbins, D 2013, Mission Impossible: Monitoring Municipal Fiscal Sustainability and Stress in Michigan. J.of Public Budgeting, Accounting, and Financial Management, vol.23, no.3, pp.522-555.

28. Cabaleiro, R, Buch, B, Vaamonde, A 2012, Developing a Method to Assessing the Municipal Financial Health. American Review of Public Administration, vol.43, no.6, pp.729-751.

29. Cuadrado-Ballesteros, B, Mordan, N, Garcia-Sanchez, IM 2014, Is Local Financial Health Associated with Citizens Quality of Life? Soc Indic Res, vol.119, pp.559-580.

30. Kloha, P, Carol, SW, dan Kleine, R 2005, Developing and Testing a Composite Model to Predict Local Fiscal Distress, Public Administration Review, vol.65, no.3, pp.313-323.

31. Trussel, JM, dan Patrick, PA 2009, A Predictive Model of Fiscal Distress in Local Government, J.of Public Budgeting, Accounting, and Financial Management, vol.21, no.2, pp.578-616

32. Priyambodo, VK dan Ritonga, I 2014, Pengklasteran Pemerintah Daerah untuk Memaksimalkan Analisis Kondisi Keuangan Pemerintah Daerah, Simposium Nasional Akuntansi XVII. Mataram 